2003

\title{
Decoupling 'Terrorist' from 'Immigrant': An Enhanced Role for the Federal Courts Post 9/11
}

Victor C. Romero

Penn State Law

Follow this and additional works at: http://elibrary.law.psu.edu/fac_works

Part of the Civil Rights and Discrimination Commons, Constitutional Law Commons, Criminal

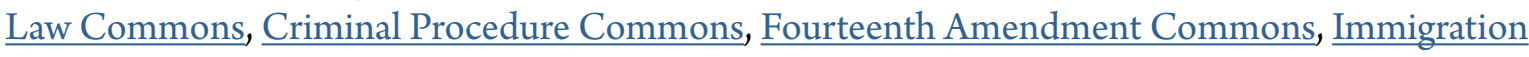
Law Commons, and the National Security Law Commons

\section{Recommended Citation}

Victor C. Romero, Decoupling 'Terrorist' from 'Immigrant': An Enhanced Role for the Federal Courts Post 9/11, 7 J. Gender, Race \& Just. 201 (2003).

This Article is brought to you for free and open access by the Faculty Works at Penn State Law eLibrary. It has been accepted for inclusion in Journal Articles by an authorized administrator of Penn State Law eLibrary. For more information, please contact ram6023@psu.edu. 


\title{
Decoupling "Terrorist" from "Immigrant:" An Enhanced Role for the Federal Courts Post 9/11
}

\author{
Victor C. Romero*
}

\section{THE Link BeTwEEn Foreign AFFAIRS AND IMMIGRATION}

Immigration law is traditionally understood to encompass the rules that govern foreign citizens' entry into and departure from the United States, and may therefore be seen as an important domestic arm of the nation's foreign policy power. Immigration law is the exclusive purview of the federal government. ' While there are times when federal law might have unintended effects upon noncitizens, ${ }^{2}$ as a vehicle for effectuating foreign policy, immigration law can serve as an effective complement. For example, if the U.S. declares war on Iraq, it might make sense to exclude all Iraqi citizens from immigrating to the United States, not just for our own citizens' security, but for theirs as well.

But what should our immigration laws say when the object of our foreign policy is not another nation, but a multinational guerrilla movement such as alQaeda? How does the U.S. balance its national security concerns against fair treatment of the individual noncitizens affected by its immigration laws? Just last year, Congress passed a law requiring greater scrutiny of visa applications

\footnotetext{
* Professor of Law, Penn State, The Dickinson School of Law. B.A. Swarthmore; J.D., University of Southern California. E-mail: VCRI@PSU.EDU. This essay grows out of remarks I gave at the University of lowa College of Law for The Journal of Gender, Race \& Justice's Symposium, "American Presence Abroad: U.S. Foreign Policy \& Its Implications on Gender, Race \& Justice"; I thank Kevin Sul and Nettie Dennis for inviting me to participate. I would also like to thank Raquel Aldana-Pindell, Sameer Ashar, and Kevin Johnson for useful advice on an early draft of this piece; Barbara Brunner for her invaluable research assistance; and most especially, my wife, Corie, my children, Ryan and Julia, and my family in the Philippines for their constant love and support. All errors that remain are mine alone.
}

1. See, e.g., Edye v. Robertson, 112 U.S. 580 (1884) (upholding a federal statute regulating immigration as a constitutional exercise of the foreign commerce clause power). With the recent passage of federal legislation in the areas of welfare reform and crime that have arguably devolved some power over alienage to the states, a recent New York University symposium has asked whether such devolution of immigration power is desirable. See, e.g., Victor C. Romero, Devolution and Discrimination, 58 N.Y.U. ANN. SURV. AM. L. 377 (2002) (analyzing the effect of immigration devolution on people of color and gays and lesbians).

2. See, e.g., Victor C. Romero, Equal Protection Held Hostage: Ransoming the Constitutionality of the Hostage Taking Act, 91 Nw. U. L. REV. 573 (1997) (arguing that federal hostage kidnapping statute violates the equal protection rights of noncitizens when invoked in garden-variety domestic kidnapping cases) 
from nationals of countries that sponsor terrorist activity. ${ }^{3}$ Clearly, not every visa applicant from North Korea is a terrorist, and yet it would be imprudent not to consider North Korea's past practices in ruling upon the application. On the other hand, is it fair to subject every single person from North Korea to increased scrutiny in the name of fighting terrorism when we are not (nor will we likely be) at war with North Korea? And what of North Koreans who might already be in this country? Should they all be deported, detained and screened for possible deportation, or interrogated about their links to terrorism?

\section{IMMIGRATION AS A TOOL IN THE WAR AGAINST TERRORISM}

In what ways may our immigration laws requiring the exclusion or removal of noncitizens assist in the war on terrorism? Even if technological advances permitted us to infallibly determine whether a noncitizen was a terrorist or not, would immigration law be used to either exclude that individual at the border or remove her from the country? In close cases, the answer is probably "no." On the one hand, ridding the nation of a dangerous individual prevents her from directly threatening the country; on the other, deporting the terrorist means she is still at large, allowing her to strike another day either directly (by entering without authorization across the border) or indirectly (by abetting a plan to be carried out by stateside associates). Indeed, our government is even willing to go beyond our borders to capture alleged terrorists who were never subject to our immigration controls in the first place. The government's obsession with capturing Osama bin Laden, as well as the recent slew of arrests of alleged alQaeda henchmen in Singapore ${ }^{4}$ and Pakistan, ${ }^{5}$ are examples of the lengths to which the government will strive to secure peace. In perhaps a less well-known example, the Washington Post reported that last year the government had interrogated a noncitizen who was discovered to be an al-Qaeda operative long

3. The Enhanced Border Security and Visa Reform Act of 2002, Pub. L. No. 107-173, § 306(a), 116 Stat. 543, 555, provides in pertinent part:

No nonimmigrant visa under Section $101(a)(15)$ of the Immigration and Nationality Act (8 U.S.C. $1101(a)(15)$ ) shall be issued to any alien from a country that is a state sponsor of international terrorism unless the Secretary of State determines, in consultation with the Attorney General and the heads of other appropriate United States agencies, that such alien does not pose a threat to the safety or national security of the United States. In making a determination under this sub-section, the Secretary of State shall apply standards developed by the Secretary of State, in consultation with the Attorney General and the heads of other appropriate United States agencies, that are applicable to the nationals of such states.

The State Department requires that citizens of North Korea, Cuba, Syria, Sudan, Iran, Iraq, and Libya who are at least 16 years old must fill out extra forms and appear for interviews before a U.S. consular officer. BUREAU OF CONSUlaR AfFaiRs, U. S. DEP'T OF STATE, NOTICE, available at http://www.travel.state.gov/section306.html (last visited Feb. 11, 2003).

4. Ellen Nakashima \& Allan Sipress, Singapore Announces Arrest of 21 Militants, WASH. PoST, Sept. 17, 2002, at Al4.

5. Michael Elliot, Reeling Them In, TIME, Sept. 23, 2002, at 35. 
after he had left the United States. ${ }^{6}$ Thus, as a theoretical matter, if the government discovers a particularly dangerous terrorist among the noncitizens it is investigating, it will likely invoke its criminal laws to prosecute the person for treason or subversion, rather than its immigration powers to deport or exclude.

Why, then, has Attorney General Ashcroft used immigration proceedings to seek out terrorists? Following the September 11 attacks, the Immigration and Naturalization Service (INS) arrested and detained approximately one thousand mostly Arab and Muslim noncitizens for immigration code violations in an effort to uncover possible terrorists among them. ${ }^{7}$ Notwithstanding the questionable desirability of deporting a known terrorist, using immigration rather than criminal proceedings to screen persons makes sense from the government's perspective. First, the process gives the government the most number of remedial options: if it decides a noncitizen is not a terrorist, it can deport her; if she is a terrorist, it can charge her criminally. In addition, the government is able to take advantage of the administrative and civil nature of immigration proceedings to aggressively prosecute its claims without providing as much due process protection to the individuals charged. ${ }^{8}$ For example, because attorneys are not automatically provided to noncitizens in deportation proceedings, ${ }^{9}$ the government is at a distinct advantage in investigating possible

6. Assoc. Press, Deported Man Said to Have Al Qaeda Tie, WASH. POST, Aug. 11, 2002, at A 19. An even more depressing example is that Mohammed Atta, one of the key $9 / 11$ hijackers, was arrested for a traffic violation in Florida in July 2001; he was released when officials did not uncover a prior warrant for his arrest from a neighboring county. Charlie Weaver \& Robert Ulrich, $\mathrm{Mr}$. Magoo v. The Terrorists, WASH. TIMES, Aug. 5, 2002, at A17, available at 2002 WL 2915511 ("The simple, horrible truth is this: Atta wasn't detained because the CIA, FBI, INS and Florida lawenforcement agencies didn't have the technology to share information. They still don't.").

7. See Susan M. Akram \& Kevin R. Johnson, Race, Civil Rights, and Immigration Law After September 11, 2001: The Targeting of Arabs and Muslims, 58 N.Y.U. ANN. SURV. AM. L. 295, 331 (2002).

8. Under the plenary power doctrine, Congress is generally immune from judicial oversight even with respect to procedural due process claims. See, e.g.. United States ex rel. Knauff v. Shaughnessy, 338 U.S. 537, 544 (1950) ("Whatever the procedure authorized by Congress is, it is due process as far as an alien denied entry is concerned."); Shaughnessy v. United States ex rel. Mezei, 345 U.S. 206, 210 (1953) ("Courts have long recognized the power to expel or exclude aliens as a fundamental sovereign attribute exercised by the Government's political departments largely immune from judicial control."). 1 have argued elsewhere that, assuming the doctrine's continued resilience, it might behoove the growing Asian and Latino/a communities of color to build coalitions with other like-minded groups to seek more favorable immigration legislation. See Victor C. Romero, On Elian and Aliens: A Political Solution to the Plenary Power Problem, 4 N.Y.U. J. Legis. \& PUB. POL'Y 343 (2000-01). See also Kevin R. Johnson, Civil Rights and Immigration: Challenges for the Latino Community in the Twenty-First Century, 8 LA RAZA L.J. 42 (1995) (making a similar case with respect to the Latino community).

9. Counsel at removal hearings appear "at no expense to the Government." INA $\S$ 240 (b)(4)(A), 292; 8 U.S.C.A. $\$ \S 1229 \mathrm{a}(\mathrm{b})(4)(\mathrm{A}), 1362$ (West 2002). Moreover, although there is no Sixth Amendment right to counsel at removal hearings (because they are not criminal proceedings), Fifth Amendment due process limitations do apply. See STEPHEN H. LEGOMSKY, IMMIGRATION AND REFUGEE LAW AND POLICY 663-64 (3d ed. 2002). Federal courts are understandably reluctant to find Fifth Amendment violations absent truly egregious conduct in specific cases, a standard common within constitutional immigration law. See, e.g., Reno v. Arab-American AntiDiscrimination Committee, 525 U.S. 471, 491 (1999) ("To resolve the present controversy, we need not rule out the possibility of a rare case in which the alleged basis of discrimination is so outrageous 
terrorist links in the context of deportation than if it had to proceed in a criminal court. Second, given its limited resources and the similar profiles of the 9/11 bombers (all young, male Middle Eastern nationals ${ }^{10}$ ), focusing government efforts on immigration violators provides it with a legitimate method for killing two birds with one stone: the government is able to enforce our immigration laws while simultaneously enhancing our national security (or at least attempting to do so ${ }^{11}$ ). Third, the government implicitly knows that by targeting immigration violators only, ${ }^{12}$ it likely has the support of the majority of the public still grieving after $9 / 11^{13}$ and the backing of constitutional immigration law, which has left decisions regarding the ingress and egress of noncitizens to the political branches. ${ }^{14}$

\section{OVERRELIANCE ON IMMIGRATION POWER UNDERESTIMATES CITIZEN THREATS WHILE HEIGHTENING MARGINALIZATION OF OUTSIDERS}

Despite the arguable efficiency of the Ashcroft plan, there are similarly

that the foregoing considerations can be overcome.").

10. Aside from the executive branch's decision to detain Arab and Muslim noncitizens, it has also developed anti-terrorism immigration strategies based on age and gender. The Bureau of Consular Affairs now requires all noncitizen men between the ages of sixteen and forty-five to file a supplementary visa application, yet another measure that is broadly over- and under-inclusive, as Israel's experience with suicide bombers of all ages and genders illustrates. See BUREAU OF Consular affairs, U.S. Dep'T of State, Fact Sheet: Initiatives by the Bureau of CONSUlar AFFaIRS TO ENHANCE NATIONAL SECURITY (Sept. 5, 2002), available at http://www.state.gov/coalition/cr/fs/13316.htm.

11. A recent N.Y.Times/CBS News poll revealed that, since the $9 / 11$ attacks, many are skeptical of the government's anti-terrorism efforts and their effectivity. See Adam Clymer \& Janet Elder, Poll Finds Unease on Terror Fight and Concerns About War on Iraq, N.Y. TIMES, Sept. 8, 2002, at Al ("Americans increasingly doubt that their government has done enough to protect them against terrorist attacks. . . .). Some polled, like Mary Wool, believe that enhanced security at airports, for instance, is "just harassment and to make people think they are doing something." $I d$.

12. As widely reported in the press, for a time, Ashcroft wanted broader powers of investigation generally, hoping that Congress would provide such authorization in the USA PATRIOT Act. See, e.g., Eric Lichtblau et al., After the Attack, Security Clampdown, L.A. TIMES, Sept. 17, 2001, at A9, available at $2001 \mathrm{WL} 2518723$. While not a paragon of restraint, the resulting legislation is certainly less draconian. See USA PATRIOT Act of 2001, Pub. L. No. 107-56, 115 Stat. $272(2001)$

13. In the N.Y. Times poll cited supra note 11, two-fifths of the respondents believed that the government had not done enough since $9 / 11$ to protect them against another terrorist attack; one of those polled suggested initiating "things like background checks on people who go in and out of the country" as a means by which such additional security could be achieved. Clymer \& Elder, supra note $\mid 1$, at $\mathrm{A} 1$.

14. See, e.g., Chae Chan Ping v. U.S., 130 U.S. 581 (1889); Kaoru Yamataya v. Fisher, 189 U.S. 86 (1903); Oceanic Steam Navigation Co. v. Stranahan, 214 U.S. 320,339 (1909) ("[O]ver no conceivable subject is the legislative power of Congress more complete than it is over [the admission of aliens]."). See also cites supra note 8. This use of immigration law to effectuate ideological exclusion is also not new. Following worker strikes in 1916 and 1917, Congress used immigration law to weaken the influence of the Industrial Workers of the World, a labor organization critical of capitalism. By the 1940s and 1950s, the "red scare" had reached epidemic proportions, extending the government's investigations to alleged citizen dissidents. See David Cole, Enemy Aliens, 54 STAN. L. REV. 953, 995-97 (2002). 
strong reasons to be skeptical about immigration law's ultimate effectivity as an anti-terrorist device. Assuming political support remains high, once Ashcroft is done focusing on Arab and Muslim immigration violators, he may set his sights on other high priority deportees such as aggravated felons, and so on down the government's list. Even if the government was able to rid the nation of all immigration violators, it might do so at the risk of not as actively combating citizen terrorism because of the added constitutional and criminal law safeguards afforded U.S. nationals. John Walker Lindh ("the American Taliban") and Jose Padilla ("the Dirty Bomber") are but two examples of alleged U.S. citizen terrorists. While these two have received much press, ${ }^{15}$ little is known in the general public about the government's efforts to investigate U.S. citizen terrorist cells, except perhaps for the hounding of Dr. Steven Hatfill in connection with last year's anthrax attacks. ${ }^{16}$ In contrast, the continued detention and investigation of immigration violators for possible terrorist links has received unending press coverage over the past year. ${ }^{17}$ Moreover, one should not underestimate the emotional, economic, and psychological toll placed on anyone subject to intense government scrutiny, especially upon persons like immigrants who, by law, already receive fewer statutory and constitutional protections than U.S. citizens.

In response, the government might argue that its efforts, despite their sometimes great costs to individual noncitizens, inure to the benefit of the

15. John Walker Lindh and Jose Padilla were Time.com's "Person of the Week," for example, on Jan. 25, 2002 and June 14, 2002, respectively. A scan of CBSnews.com revealed that as of Oct. 17,2002 , that service alone had reported eighty-eight times on John Walker Lindh and twenty-two times on Jose Padilla. For more on Lindh, see John Riley, Lindh Admits Guilt, NEwSDAY (New York City), July 16, 2002, at A03, available at 2002 WL 2753747; Michael Hedges, Lindh Faces Court, Hous. Chron., Jan. 25, 2002, at 1, available at 2002 WL 3237490. For more on Padilla, see Amanda Ripley, The Case of the Dirty Bomber, TIME, June 24, 2002, at 28, 29-32 (describing Jose Padilla's transformation from Chicago street gang member to Al-Qaeda operative); Walter Pincus, WASh. POST, Captive's Clues Foiled Plot, INT'L Herald TRIB., June 12, 2002, at 1, 4; Caroline Daniel \& Jeremy Grant, Ex-Gang Member Who Went Unnoticed, FiN. TIMES (London), June 11, 2002, at 11, available at 2002 WL 21714781; David G. Savage, Detention of A Citizen Questioned Law: 'Dirty' Bomb Suspect Was Secretly Held and Hasn't Been Charged, L.A. TIMES, June 12, 2002, at A1, available at 2002 WL 2482660 . This is not to suggest that the two are in fact terrorists. While Lindh has plead guilty to terrorist activity, Padilla's lawyers are still fighting his designation as an enemy combatant. Compare Riley with Savage, supra.

16. See, e.g., Ron Kampeas, Anthrax Probe Figure to Undergo Blood Test, CHI. SUN-TimeS, Aug. 26, 2002, at 5, available at 2002 WL 6470061; Susan Schmidt, Evidence Lacking as Probe of Scientist in Anthrax Scare Intensifies, WASH. POST, Aug. 15, 2002, at A07, available at $2002 \mathrm{WL}$ 24827825; Curt Anderson, Justice Dept. Denies Casting Suspicion on Germ Researcher, BOSTON GLOBE, Dec. 13, 2002, at A51, available at $2002 \mathrm{WL} 101988628$. Indeed, the government's aggressive investigation of Hatfill suggests that, had it more resources and were it not necessary to provide more criminal due process, perhaps it would treat just as seriously perceived national security threats by U.S. citizens as it would those by noncitizens. Ashcroft's lobbying Congress for broader investigatory powers immediately after 9/11 supports this view. See supra note 12 .

17. Of course, this unequal press coverage might be more a reflection of the press's priorities than existing reality. See supra text accompanying note 15 (arguing inordinate amount of attention paid to Lindh and Padilla when general media coverage of domestic U.S. citizen terrorism receives little press coverage as compared to investigations of noncitizens). But while it is possible that the government is pursuing with equal fervor the investigation of U.S. citizen-based terrorism, I, for one, am skeptical that this is actually happening. 
country writ large. The sacrifice of the few is worth the well-being of the many. Of course, this argument would be more persuasive if the government could show definitively that the terms "terrorist" and "immigration violator" are synonymous, or that there is a sufficiently high correlation between the two. As the Lindh and Padilla cases remind us, the government's case is based, at best, on educated guesses and statistical probabilities, and at worst, on stereotypical presumptions. ${ }^{18}$

On the latter point, Ashcroft's Arab-Muslim immigration dragnet exacerbates racial, religious, and gender stereotypes. As many have documented, exclusively targeting certain groups, even among noncitizens, is unacceptably both over- and under-inclusive. ${ }^{19}$ Targeting certain groups is overinclusive because interrogating and detaining thousands of noncitizens based on accidents of birth offends our notions of liberal equality and individual civil rights. It is also underinclusive because, as mentioned before, there are U.S. citizens and other foreign nationals who may also be terrorist threats. ${ }^{20}$

\section{PRESERVING INDIVIDUAL RIGHTS IN THE WAR AGAINST IMMIGRANT TERRORISM: AN IMPORTANT ROLE FOR THE COURTS}

As a final rejoinder, the government might respond that in enacting and enforcing general immigration policy, it has no choice but to paint wide brush strokes. Congressional statutes are inherently broad so as to be of sufficiently general applicability. Executive enforcement strategies are equally so in order to provide sufficient flexibility to personnel. Indeed, our constitutional immigration law sanctions such extensive power, understanding that the political branches have the institutional competence to best engage in foreign relations, to which

18. See supra note 15.

19. See generally Akram \& Johnson, supra note 7; Leti Volpp, The Citizen and the Terrorist, 49 UCLA L. REV. 1575 (2002); Sameer Ashar, Immigration Enforcement and Subordination: The Consequences of Racial Profiling After September 11, 34 CONN. L. REv. 1185 (2002); Victor C. Romero, Proxies for Loyalty in Constitutional Immigration Law: Citizenship and Race After September 11, DePAUL L. REV. (forthcoming 2003); Cole, supra note 14.

20. The USA Patriot Act has also been used to cut off funding sources for terrorism organizations. See, e.g., Cosmo Macero, Jr., Anti-Terror Inc. Sets Up Shop in Boston, BostoN HERALD, May 6, 2002, at 021, available at 2002 WL 4075268 ("'We have to . . thwart potential terrorist activity any way we can,' U.S. Attorney Michael Sullivan said after the verdict was returned - marking the first conviction nationwide under the 6-month-old Patriot Act. 'One way is to disrupt the flow of money to terrorist organizations."'); see also Cole, supra note 14, at 1002 (noting that pursuant to the USA Patriot Act, the federal government has aggressively investigated two U.S.based holding companies for their alleged financial support of terrorism). Similarly, the government should not neglect domestic terrorism networks such as hate groups that have financial links to antiimmigration organizations. The Southern Poverty Law Center (SPLC), for example, has traced the funding of several anti-immigration groups, some of which have been designated by the SPLC as hate groups, to Dr. John Tanton, a Michigan physician. See Southern Poverty Law Center, The Puppeteer, INTElligenCE REPORT, Summer 2002, at 44-51 ("The organized anti-immigration 'movement,' increasingly in bed with racist hate groups, is dominated by one man.") available at http://www.splcenter.org/intelligenceproject/ip-index.html. 
immigration law is linked through its regulation of migrants. ${ }^{21}$ Moreover, there are no significant signs that the public is willing to shelve immigration policy as a weapon in the war against terrorism, and thus we cannot expect that the political branches ${ }^{22}$ will either. And perhaps that is as it should be. Our national policies, for better or worse, are determined by our representative government, duly elected by our voting public, and in theory, they try to capture majoritarian sentiment. If, despite the apparent flaws in implementation, most of the public feels comfortable using immigration law to combat terrorism, then our republican democracy should support that.

More interestingly, the support for Ashcroft's anti-immigrant, profilecharged dragnet may have a broader base than simply among middle-class white American voters. While most post-1965 immigration has come from Asia and Latin America, and while racial profiling has been roundly denounced by many in the African- and Latino/a-American communities, immigration policy has long been a contested playing field. Thus, it may very well be that the much touted demographic "browning" of America may not lead to better treatment of noncitizens, especially post-9/11, for a number of reasons. First, Professor Angela Dillard has documented the growth of a multicultural conservative movement ${ }^{23}$ exemplified most visibly perhaps by several of Bush's key cabinet members-Colin Powell (Secretary of State), Condoleeza Rice (National Security Adviser), and Norman Mineta (Secretary of Transportation)-that might, at the margin, be more sympathetic to national security concerns linked to restricting immigration than to more traditional egalitarian principles. Second, both lawful and undocumented immigration will likely continue to be wedge issues among and within communities of color. Many African Americans oppose even lawful immigration on the grounds that it affects native blacks' employment prospects, ${ }^{24}$ while recent immigrants from Asia and Latin America are often

\section{See supra note 8.}

22. Note, however, that the political branches have not completely abdicated leadership in protecting immigrant rights even post-9/11. For example, realizing that the Patriot Act's implicit prohibition against foreign students enrolling in part-time classes would have had a devastating effect upon part-time commuter residents along the Canadian and Mexican border, Congress passed the Border Commuter Student Act, Pub. L. 107-274, 116 Stat. 1923 (2002), which creates a new class of nonimmigrant visas for such students.

23. See generally ANGEla Dillard, GUESS WHO'S COMING to DinNeR Now? Multicultural CONSERvatism IN AMERICA (2001) (describing the rise of the multicultural conservative movement).

24. See, e.g., Kevin R. Johnson, Racial Hierarchy, Asian Americans, and Latinos as "Foreigners," and Social Change: Is Law The Way to Go?, 76 OR. L. REv. 347, 359-60 (1997).

In more modern times, African Americans, fearing that immigration adversely impacts their community by driving down wages, supported restrictionist immigration laws and policies that have disproportionate impacts on immigration from Asia and Latin America. In addition, conflict between Blacks and Asians in South Central Los Angeles and between Blacks and Latinos in other parts of the country have provided fuel to calls for immigration restriction. (internal citations omitted).

ld. 
unsympathetic to civil rights claims by undocumented immigrants ${ }^{25}$ (hence the popularity of California's Proposition 187 eliminating many public benefits for undocumented persons during the early 1990s). Following 9/11, Time magazine reported undocumented Mexican laborers upset at the enhanced border security wrought by the terrorist attacks, blaming the situation on the "damn Arabs."26 Thus, Ashcroft will find some unlikely allies even among citizens and immigrants of color.

While the likelihood that vigilant immigration enforcement will continue to be the majority's will, our country also subscribes to an equality principle designed to protect the least powerful among us. The under-policing of U.S. citizen terrorists, and the perpetuation of invidious stereotypes evident in our current immigration policy, undermines equality in two ways. First, because immigration law is premised on the unequal status of U.S. citizens and noncitizens, broad policies that apply only to noncitizens, even those enacted in the name of national security, are likely to widen the citizen-noncitizen divide and enhance tensions between the two groups. ${ }^{27}$ Second, to the extent that most U.S. immigrants today are people of color from Asia and Latin America, the unintended burden of stringent immigration enforcement will fall upon racial outsiders, exacerbating tensions between whites and nonwhites. ${ }^{28}$

Fortunately, there is an integral institution in our democracy designed and particularly well-suited to protect individual claimants-the federal courts. While they have long deferred to Congress and the Executive in setting immigration policy, the courts have not shied away from providing needed checks and balances in instances of political branch overreaching. ${ }^{29}$ Most recently, some

25. See, e.g., Kevin R. Johnson, Immigration and Latino Identity, 19 ChiCANo-Latino L. REV. 197, 201 (1998) (describing support among some Latino/as for Proposition 187) (internal cite omitted).

26. Peter Katel, Slamming the Door, TimE, Mar. 11, 2002, at 37 (quoting Mexican deportee Jose Guzman: "Damn Arabs . . Ever since the towers, it's 'Out of here." ).

27. Ethnic, racial, and religious profiling drives a wedge between citizens and noncitizens in communities of color. For example, rather than challenging anti-immigrant laws, U.S. citizens of Arab descent might seek to avoid further scrutiny by privileging their citizenship status over their ethnicity, unintentionally leaving their noncitizen counterparts, many of whom are innocent, subject to more intense scrutiny. See, e.g., Cole, supra note 14, at 997-98 (describing the case of a woman who was able to avoid deportation due to her allegedly subversive writings by successfully proving her U.S. citizenship).

28. As Professor Cole has stated, "What we are willing to do to noncitizens ultimately affects what we are willing to do to citizens. In the long run, all of our rights are at stake in the war against terrorism." Cole, supra note 14, at 1003. Relatedly, Professor Kevin Johnson has argued that the government's adverse policies towards noncitizens of color suggests how they might want to treat citizens of color, but are prohibited from so doing by the constitution. See Kevin R. Johnson, Race, the Immigration Laws, and Domestic Race Relations: A "Magic Mirror" into the Heart of Darkness, 73 IND. L.J. 1111, 1119-20 (1998); Kevin Johnson, September 11 and Mexican Immigrants: Collateral Damage Comes Home, DePAUL L. REV. (forthcoming 2003) ("Although Arab and Muslim noncitizens felt the brunt of the civil rights deprivations in the immediate aftermath of September 11, immigrants generally will suffer the long term consequences of the many measures taken by the federal government in the name of fighting terrorism.").

29. To have true equal protection regarding the impact of immigration laws between U.S. 
courts have curbed Executive zealotry by slowing down the juggernaut, forcing the Attorney General to follow time-honored due process procedures. First, the federal Foreign Intelligence Surveillance Court chided the FBI for misleading the courts in seventy-five alleged terrorism cases, all of which involved noncitizens. ${ }^{30}$ Second, the Sixth Circuit Court of Appeals upheld a lower court decision opening immigration proceedings to the public and press unless the INS could prove specific threats to national security. ${ }^{31}$ It is fitting that in the second case, Detroit Free Press v. Ashcroft, the opinion was penned by Sixth Circuit Judge Damon Keith, an African-American jurist long supportive of civil rights. ${ }^{32}$ As Congress and the Executive Branch continue to experiment with how to prudently and effectively use their immigration power in the war against terrorism, ${ }^{33}$ it will be up to the federal courts to ensure that individual

and non-U.S. citizens is likely impossible because these groups are by definition not similarly situated for purposes of immigration law. However, outside of immigration law - the law affecting general civil rights - foreigners and citizens are both groups of autonomous individuals linked together by the mutual desire to be treated equally under the law. Of course, the problem with the equal protection claim is that equality may be achicved by eliminating the disadvantages visited upon the minority group or by increasing the disadvantages suffered by the majority. During the oral argument of the celebrated death penalty case, McCleskey v. Kemp, Justice O'Connor asked, for example, whether the disparity in sentencing visited upon killers of black versus white people might be cured by "execut[ing] more people." EDWARD LAZARUS, Closed CHAMBERS 203 (1998).

30. See In re All Matters Submitted to the Foreign Intelligence Surveillance Court, $21 \mathrm{~F}$. Supp. 2d 611 (2002), abrogated, 310 F.3d 717 (2002) (the lower court approved, with conditions, the Attorney General's request for broader surveillance powers consistent with the Patriot Act, and the appeals panel removed those conditions). Although the U.S. Foreign Intelligence Surveillance Court of Review reversed the lower court, granting the Attorney General's motion to remove any of the lower court's conditions on its surveillance requests, the appeals panel did not overturn the lower court's finding that the FBI had misled the court in approximately seventy-five cases for which it sought court approval pursuant to the Foreign Intelligence Surveillance Act. Id. Professor Raquel Aldana-Pindell explores the scope of the executive branch's exercise of its national security powers versus its criminal law enforcement powers, arguing that the current, domestic so-called "war on terrorism" should be viewed to be the latter, subjecting executive action to greater judicial scrutiny. See Raquel Aldana-Pindell, The 9/11 "National Security" Cases: Three Principles Guiding Judges' Decisionmaking, OR. L. REV. (forthcoming 2003).

31. Detroit Free Press v. Ashcroft, 303 F.3d 681 (6th Cir. 2002). Most recently, the Sixth Circuit Court of Appeals declined the Justice Department's invitation to review the panel's decision en banc. See David Ashenfelter \& Niraj Warikoo, Court Gives Public Access to Deportation Hearing, Detrort Free Press, Jan. 23, 2003, at 1. But see North Jersey Media Group, Inc. v. Ashcroft, 308 F.3d 198 (3d Cir. 2002) (ruling secret proceedings constitutional). This conflict between the Third and Sixth Circuits has led to speculation that the Supreme Court might want to resolve this issue before long. See Adam Liptak \& Robert Hanley, Citing 9/11. Appeals Cotrt Upholds Secret Hearings, N.Y. TIMES, Oct. 9, 2002.

32. There is, of course, no guarantee that a judge of color will be more vigilant in curbing excessive executive and legislative zeal; one need think only of Justice Clarence Thomas to realize the danger of such essentialist thinking. Indeed, immigration has long been a wedge issue between people of color (e.g., African-Americans against Latino/a- and Asian-Americans) and within certain groups themselves (e.g., there was sizeable Latino support for Proposition 187, California's antiundocumented immigration initiative). But it is also true that many people of color - along with other marginalized groups - understand oppression and inequality, making empathy a true possibility.

33. Alternatives to aggressive immigration enforcement in combating terrorism include the development of better technologies that do not unduly trample individual privacy rights and better utilization of security policies designed to thwart terrorist activity, such as bag-matching at airports. See, e.g. Karen Kaplan, Fighting Terrorism, L.A. TIMES, Sept. 20, 2001, at T1, available at 2001 
noncitizens are provided sufficient protection in this post-9/11 world.

The federal courts have at least four good reasons to be skeptical of the federal political branches, especially during times of real or perceived crisis. First, while the legitimate goal of immigration law enforcement is deportation, Ashcroft's true objective in targeting noncitizens appears to be criminal prosecution for terrorism and subversion. After all, why would the INS risk letting a terrorist get away-which is what the deportation remedy would be $\mathrm{e}^{34}$ rather than prosecuting him with the goal of life imprisonment or the death penalty? Thus, the constitutional defense of political plenary power is even less persuasive, especially when, as here, the foreign threat comes not from another nation (thus justifying the political branches' plenary international relations power), but instead from a multinational, multiethnic guerilla force that uses unconventional methods of attack, as it did on $9 / 11$.

Second, we can well expect that Ashcroft will dispatch criminal law enforcement and immigration agents that might be tempted, at the margin, to play fast and loose with suspects' civil liberties, as evidenced by the FBI's deceptive practices in over seventy-five post-9/11 cases. ${ }^{35} \mathrm{I}$ do not mean to suggest bad faith on the agents' part; indeed, I understand that if one believes that one is restoring "the rule of law to the immigration law," ${ }^{36}$ as Assistant Attorney General Viet Dinh has stated, one's noble ends might justify a liberal interpretation of otherwise suspect governmental means. Indeed, the recent decision to split the service and enforcement functions of the INS was prompted in part by the desire to ensure that civil servants long bent on enforcement do not end up in the petition processing section looking for ways to deny admission to family members of lawful permanent residents. ${ }^{37}$ It is the role of impartial

WL 2519398 (describing various technologies under development including advanced explosive and trace metal detection machines, facial recognition systems, and fingerprint identification devices); Guy Gugliotta, Tech Companies See Market for Detection, WASH. POST, Sept. 28, 2001, at A08, available at 2001 WL 28360472 ("For several years, cutting-edge identification and detection technologies have helped specialists in the battle against terrorism, but the Sept. 11 attacks on the Pentagon and the World Trade Center could transform these once exotic gadgets into everyday tools of airport safety."); John Hughes, New Baggage Screening Raises Concerns, CHI. SUN-TIMES, Dec. 31,2002 , at 50, available at 2002 WL 6484396 ("The government will use machines to screen bags at most airports. At about 30 airports, it will also use bomb-sniffing dogs, manual searches and bag matching, a process that ensures no unaccompanied bags are put on planes.").

34. It is conceivable that we deport suspected terrorists to an ally that engages in torture so as to extract valuable information from the suspects without having to ourselves violate human rights law. Our decision to leave terror suspect Mohammed Heidar Zammar in the hands of the Syrian government rather than taking custody ourselves was allegedly motivated by similar goals. See Mitch Frank, Help from an Unlikely Ally, TIME, July 1, 2002, at 38 ("Some in the German government are accusing the U.S. of having one of their citizens taken for interrogation to a country where human rights don't count for much. In the war on terrorism, Syria--a notorious haven for terrorists--is the U.S.'s latest ally of convenience.").

35. See, e.g., Philip Shenon, Secret Court Says It Was Misled by FBI, SAN Diego UnIONTRIB., Aug. 23, 2002, at A01.

36. Dena Bunis, Security A Focal Point of Immigration Policy, Orange CounTy Reg. (Cal.), Sept. 9, 2002, available at 2002 WL 5459479.

37. See, e.g., A New Home for the INS, WALL ST. J., Nov. 29, 2002, at A14, available at 2002 WL-WSJ 103127398 ("The reorganization splits the enforcement functions, such as border control, 
courts to ensure that the constitutional equality principle is not unduly compromised.

Third, history is replete with examples of federal government zealotry, and the federal courts would do well not to bow to majority sentiment especially when racial, ethnic, religious, gender, and age stereotypes are reinforced at the expense of the egalitarian ideal. The legacy of Brown v. Board of Education ${ }^{38}$ should be that the Supreme Court will never reaffirm Korematsu's ${ }^{39}$ principles. $^{40}$

And fourth, controlling political overreaching enhances our standing abroad. As I mentioned at the very beginning of this piece, domestic immigration policy and international relations are indeed interrelated, and as such, if we value human rights at home, our ambassadors abroad will have a stronger case when they accuse other nations of transgressing civil liberties. Nicholas Kristof, describing the near month-long detention without charge or cause of a Yemeni "material witness" married to a U.S. citizen, summarized the argument thusly: "Imprisoning a Yemeni because he is a Yemeni will not destroy our freedoms. But it undermines our ability to project our values abroad." ${ }^{41}$

from service functions like visa processing..."); Charlotte Stichter, Homeland Security Meets Immigration, 2002 IMMIGR. BRIEFINGS 1.

38. Brown v. Board of Education, 347 U.S. 483 (1954) (striking down government-enforced racial segregation as unconstitutional).

39. Korematsu v. U.S., 323 U.S. 214 (1944) (upholding as constitutional the wartime incarceration of U.S. citizens and noncitizens of Japanese ancestry).

40. As critical race theorists are quick to point out, there are no guarantees that the courts will be any less nativist, racist, or sexist than any other institution. See.e.g., FRANCISCO VALDES ET AL., CROSSROADS, DIRECTIONS AND A NEW CRITICAL RACE THEORY 1-2 (2002) (challenging the notion that racism is aberrational, asserting instead a "systemic analysis of the structures of subordination"). Even Justice Earl Warren, the architect behind Brown v. Board of Education, supported the internment of Japanese and Japanese-Americans as governor of California during World War II. See Sumi K. Cho, Redeeming Whiteness in the Shadow of Internment: Earl Warren, Brown, and a Theory of Racial Redemption, 40 B.C. L. REv. 73, 73 (1998) (arguing that despite his reputation as a "civil rights icon," "Warren was a key actor in the anti-Asian movement that culminated in the 1942 internment of over 120,000 persons of Japanese ancestry, two-thirds of whom were United States citizens."). Indeed, it is possible that the only times courts will choose to intervene are when the government's conduct is outrageous by any person's standard -- for instance, beating confessions out of immigrant detainees simply because they are noncitizens or committing them to hard labor. See, e.g., Zadvydas v. Davis, 533 U.S. 678, 704 (2001) (Scalia, J., dissenting) (citing Wong Wing $v$. United States, 163 U.S. 228 (1896), which held that subjecting noncitizens to hard labor or torture for immigration violation offends due process). I also, however, take seriously the notion that all workable theories must be presented and pursued simultaneously, since one never knows when the winds of change will blow in one's favor.

41. Nicholas D. Kristof, Security and Freedom, N.Y. TIMES, Sept. 10, 2002, at A25. 
